\title{
O testemunho oblíquo em $O$ que os cegos estão sonhando?, de Noemi Jaffe, e Maus, de Art Spiegelman
}

\author{
Marcelo Ferraz de Paula ${ }^{1}$
}

Com o decorrer incessante do tempo, vão minguando os últimos sobreviventes dos campos de concentração nazista. A obsessão perversa dos dirigentes alemães em arquitetar um "crime sem testemunhas" 2 foi profusamente enfrentada por diferentes gerações de pessoas que passaram pela experiência dos Lagers e deixaram relatos que desafiam as sombras do esquecimento estratégico almejado pelos nazistas. Lidamos, contudo, em tempos atuais, com o fato de que, num futuro relativamente próximo, as últimas testemunhas diretas da Shoah desaparecerão, devido ao esgotamento natural dos corpos, numa situação, felizmente, distante daquela na qual milhões de seres foram submersos no horror dos campos de extermínio. Suas mortes poderão, enfim, lhes pertencer, para invertermos aqui uma célebre afirmação de Elie Wiesel. ${ }^{3}$ Mas que caminhos a memória percorrerá após este evento carregado de simbolismo? Estaremos livres para esquecer sem pudor?

Uma das obras que procuro examinar ao longo deste artigo expõe de modo incisivo esta guinada e as aporias que dela emanam:

\footnotetext{
${ }^{1}$ Doutor em Estudos Comparados de Literaturas de Língua Portuguesa e professor da Universidade Federal de Goiás (UFG), Goiânia, GO, Brasil. Eorcid.org/0000-0002-2641-1794. E-mail: marcelo2867@gmail.com

${ }^{2}$ Discorrendo sobre essa característica do projeto de extermínio nazista, Márcio Seligmann-Silva relembra o famoso trecho do discurso de Posen, no qual Himmler afirma que "o genocídio dos judeus seria uma 'página de glória não escrita e que nunca deveria ser escrita"” (Seligmann-Silva, 2013, p. 78, grifo do autor). O processo de eliminação dos corpos das vítimas, via câmaras de gás e fornos crematórios, a destruição de documentos quando se aproximava o fim da guerra, o tratamento estrategicamente cruel dado aos prisioneiros, para além do verossímil e do crível, são algumas das medidas, entre muitas outras, que atestam o objetivo bem calculado de apagar a história e a memória das violações cometidas, eliminando os rastros que poderiam conduzir ao esclarecimento total da verdadeira dimensão do crime ocorrido.

${ }^{3}$ Em "A morte de meu pai”, um de seus contos mais conhecidos, Wiesel enfrenta o dilema de rezar ou não o kadish para o seu pai, morto no campo de Buchenwald. Parte do conflito se dá pelo fato de que "a sua morte [do pai] nem ao menos lhe pertenceu. [...] Nenhuma conexão [há] entre ela e a vida que ele viveu. A sua morte, perdida entre a de todos os outros, nada teve a ver com a pessoa que ele havia sido" (Wiesel, 1987, p. 26).
} 
Faltam, no máximo, vinte anos para que os sobreviventes desapareçam, morram. Quando isso acontecer, outra etapa desta história vai começar e é preciso preparar-se para ela. $\mathrm{O}$ que serão os campos de concentração daqui a cinquenta anos? Um nome? A história deverá preparar-se para isso? A palavra Auschwitz será como a palavra Troia, a palavra Peloponeso, a palavra Manchúria? (Jaffe, 2012, p. 186, grifos da autora).

Quando consideramos sua dimensão coletiva, parece que a tarefa de testemunhar os eventos intestemunháveis da guerra foi, dentro de certos limites, cumprida, haja vista a quantidade de depoimentos recolhidos nos mais diferentes formatos, estilos e veículos, sintonizados (ou não) com as sucessivas ondas de memória que assumiram protagonismo no debate cultural ao longo da segunda metade do século XX. Do testemunho romanceado ao depoimento acusatório, proferido em tribunal; do desabafo eivado pelo ódio ao exercício racional que busca a compreensão ou mesmo, em alguns casos, o perdão dos algozes; relatos esteticamente pretensiosos ou despretensiosamente espontâneos; de quem testemunha com base em um projeto humanístico bem delineado ou de quem se expressa guiado pela intuitiva necessidade de verbalizar o trauma. Em última instância, a afirmação de Primo Levi, "estou em paz comigo porque testemunhei" (apud Agamben, 2014, p. 27), pode ser lida numa chave metonímica que indica, entre o alívio e a inquietude, o cumprimento, tão bem realizado quanto possível foi, de uma tarefa de memória assumida como imperativo ético por parte significativa dos sobreviventes dos campos de concentração e extermínio.

Mas voltemos à pergunta que norteia esta reflexão: como ficará a necessidade de preservar a memória do horror após o fim natural dos últimos sobreviventes? Esta é uma pergunta incômoda, em parte por ser, em certo sentido, desrespeitosamente apressada, já que as testemunhas diretas ainda existem. Entretanto, para além do desconforto que a indagação desperta, sua importância tende a crescer nos debates e embates em torno da Shoah, na medida em que muitas produções culturais se antecipam a esse futuro inescapável e formulam respostas diante da iminência deste silenciamento. Nesse sentido, são cada vez mais abundantes as obras que se estruturam a partir do que chamarei aqui de testemunho oblíquo. Essa modalidade de testemunho abarcaria parte significativa dos chamados 
"testemunhos de segundo grau" (Berger e Berger, 2001; Hirsch, 2008), produzidos por alguém que não sofreu diretamente os efeitos terrificantes da agressão, mas que conviveu com seus sobreviventes e foi subjetivamente impactado por suas histórias, vindo a assumir a responsabilidade ética de compartilhar suas cicatrizes. De modo geral, tais produções se opõem à tese radical de que o testemunho, enquanto produção discursiva vinculada à catástrofe histórica, morrerá junto com o último de seus sobreviventes. ${ }^{4}$

Podemos dizer que o testemunho oblíquo amplifica o vácuo entre a necessidade de falar sobre o horror e o reconhecimento de que não se possui as ferramentas adequadas para assegurar o compromisso de seu relato com o "real". Sua necessidade de narrar é premente, mas a matéria da qual é feito o testemunho ao mesmo tempo lhe pertence e não lhe pertence; ele dói por reconhecer o trauma do sobrevivente e, simultaneamente, dói pela culpa de não ter vivido a catástrofe, de ter sido tocado por ela sem ter tido a chance de tocá-la por dentro, já que ela lhe chega por meio da narrativa e dos silêncios de outrem. Em outros termos, o testemunho oblíquo (re)conhece o horror por intermédio, de um lado, da simbolização legada pela testemunha "verdadeira" e, de outro, pelos muitos e heterogêneos relatos sobre a catástrofe que escrutina como tentativa de autocompreensão, enformando-se sempre num embate duplo que combina o enfrentamento da catástrofe em si com o enfrentamento do(s) testemunho(s) que a ela o aproxima.

Todavia, para não exagerar o alcance e a novidade dessa proposta, é preciso lembrar que nenhum testemunho é "retilíneo". 5 Primo Levi nos lembra que a autêntica testemunha, a "testemunha integral", é aquela que fitou a górgona e que, por isso, não pode voltar para narrar. Sendo assim, mesmo a "testemunha direta" já reconhece que "falamos nós em lugar deles, por delegação" (Levi,

\footnotetext{
${ }^{4}$ Criticando essa perspectiva, ainda muito forte nos estudos sobre a Shoah, Valéria de Marco afirma que ela "decreta a extinção dessa forma literária, na medida em que deixaria de existir com a morte do último sobrevivente, e põe em risco a existência da própria literatura, ao insistir na impossibilidade de representar o horror indizível" (Marco, 2004, p. 60).

${ }^{5}$ Não podemos nos esquecer de que os testemunhos canônicos, produzidos pelos sobreviventes diretos, já se processam a partir de limites muito rígidos (linguísticos, éticos, mnemônicos, estéticos). A representação da dor extrema já demanda, pela sua matéria indizível, a utilização de uma "não língua" que, em última instância, cada vez que testemunha reconhece "a impossibilidade de testemunhar" (Agamben, 2014, p. 48).
} 
1990, p. 32). Seguindo essa linha de pensamento, podemos supor que a diferença entre o testemunho canônico e o testemunho oblíquo seria antes de grau que de gênero. O primeiro testemunha a partir de um ângulo mais estreito em relação à experiência total dos campos de concentração, isto é, fala bem próximo da morte, que observou sem ser inteiramente consumido por ela. $\mathrm{O}$ segundo se alimenta do registro primário como forma de se aproximar da cena não vivida e lidar com a memória traumática que essa narrativa faz ecoar em sua subjetividade. Partindo do reconhecimento penoso de que as testemunhas diretas já "testemunham sobre um testemunho que falta" (Agamben, 2014, p. 43), é preciso examinar com a devida precaução o modo como novas modalidades de testemunho se distanciam ainda mais da cena "real" sem com isso se omitir da necessidade, íntima e política, de voltar fidedignamente a ela, na medida em que reconhece ser por ela constituído.

Entre aqueles que se defrontam com a necessidade de formular um testemunho oblíquo estão frequentemente os amigos $\mathrm{e}$ familiares das vítimas, com enorme destaque para a figura dos filhos, lançados involuntariamente à condição de herdeiros desses traumas. ${ }^{6} \mathrm{O}$ protagonismo assumido por esses descendentes traz o desafio crítico de alargamos o conceito de testemunha, de modo a torná-lo válido para as novas exigências históricas que se apresentam ao nosso tempo, marcado por um alarmante fortalecimento de discursos fascistas. Conforme as palavras de Jeanne Marie Gagnebin (2014, p. 57; grifos da autora):

testemunha não seria somente aquele que viu com seus próprios olhos, o histor de Heródoto, a testemunha direta. Testemunha também seria aquele que não vai embora, que consegue ouvir a narração insuportável do outro e que aceita que suas palavras levem adiante, como num revezamento, a história do outro: não por culpabilidade ou

\footnotetext{
${ }^{6}$ Cumpre observar que a perspectiva dos descendentes, sobretudo dos filhos e filhas, tem chamado cada vez mais a atenção da crítica que lida com as relações entre produção cultural, violência e trauma. Seja a partir do ponto de vista dos herdeiros dos algozes, lidando com a culpa, a vergonha causada pelo colaboracionismo dos pais - como comprovam os fartos e intrigantes exemplos oferecidos pela literatura alemã desde, pelo menos, os anos 1960 - como também nos filhos das vítimas, afetados pela dor dos pais e as projeções marcadas pela incompletude (Fux, 2013b). O conceito de "pós-memória" - não adotado neste artigo - atua frequentemente como mediador no exame dessas produções.
} 
por compaixão, mas porque somente a transmissão simbólica, assumida apesar e por causa do sofrimento indizível, somente essa retomada reflexiva do passado pode nos ajudar a não repeti-lo infinitamente, mas a ousar esboçar uma outra história, a inventar o presente.

Mais do que alguém que não quer ir embora, os filhos são, conforme veremos no decorrer da análise, aqueles que não podem, ainda que queiram, se desvencilhar das memórias dos pais. Isso porque a identidade deles é ao mesmo tempo construída e obstruída pelo peso da catástrofe que paira, como mitologia viva, na memória familiar. A laboriosa necessidade de preservar e enfrentar essa memória herdada adquire alta dramaticidade nas obras resultantes da missão autoimposta pelos filhos de se tornarem uma espécie de porta-voz ou mediador entre as lembranças familiares, íntimas, e o debate público para o qual o seu testemunho é direcionado.

O que os cegos estão sonhando?, publicado em 2012 pela escritora brasileira Noemi Jaffe, e o célebre romance gráfico Maus, de Art Spiegelman, publicado entre 1980 e 1991, constituem-se como tentativas de elaboração simbólica da experiência de ser, respectivamente, filha e filho de sobreviventes dos campos de concentração nazistas e serão examinados aqui com ênfase na convergência de elementos temáticos e formais presentes nas duas obras. Destaco, sobretudo, a presença de uma nada complacente reflexão metalinguística - especialmente no reconhecimento do risco de estetização da história dos sobreviventes -, o entrecruzamento vertiginoso entre os testemunhos dos pais e o testemunho oblíquo dos filhos e o reconhecimento da responsabilidade, da culpa e do legado traumático que recaem sobre a constituição desses/as autores/as-personagens.

\section{Tudo é dilema}

O que os cegos estão sonhando? é, desde a primeira mirada, um livro inusual e desconcertante. Nele a escritora, professora e crítica literária Noemi Jaffe realiza um longo, tortuoso e penoso enfrentamento de sua condição como filha de Lili Jaffe, sobrevivente do campo Auschwitz, que se fixou no Brasil após o fim da guerra. Ao longo da obra, a autora indaga-se sobre qual seria o papel dos 
que não estiveram presencialmente envolvidos no universo concentracionário, mas que sofreram indiretamente e prolongadamente seus impactos. Seriam as novas gerações capazes de testemunhar em nome de seus antepassados? Em que medida a memória da catástrofe é hereditária? Como lidar com o risco de o testemunho oblíquo dos herdeiros converter a tragédia do sobrevivente numa mitologia familiar mistificadora?

Para enfrentar esses dilemas - e a autora faz questão de enfatizar que "tudo diante da guerra, e, mais ainda, dessa guerra, é motivo de dilema" (Jaffe, 2012, p. 137) - Noemi Jaffe se coloca como autora, narradora, intérprete e personagem de sua própria experiência como filha de sobrevivente. Assim como no livro de Spiegelman, ${ }^{7}$ a autora mobiliza diversas estratégias discursivas, variando do poético ao documental, da confissão à teorização, do memorialismo à escrita ficcional, incorporando procedimentos estéticos que lembram os processos de montagem modernista. A abundância de tons e semitons parece indicar tanto a dificuldade de lidar com uma matéria esquiva, que não pode ser satisfatoriamente examinada a partir de uma estilização uniforme, como também revela o caráter indizível da experiência com a qual se debate. Às vezes, num mesmo capítulo, a filha vai da interpretação amorosa do diário da mãe a uma reflexão histórica de amplo alcance. De um capítulo para outro, passamos de uma narrativa que imagina ficticiamente o futuro das pessoas que a mãe conheceu nos campos para um inventário poético de objetos exibidos no memorial de Auschwitz. Nesse mosaico vertiginoso, com suas fissuras e enlaces, funda-se uma imagem altamente original do horror dos campos, sem concessões aos obstáculos de verbalização que o tema provoca.

O livro é formado por três textos justapostos: o primeiro é o Diário de Lili Jaffe, escrito pela própria mãe na Suécia, logo após a libertação dos campos. O segundo, mais extenso e com uma posição nuclear, possui o mesmo título do livro e corresponde ao testemunho de Noemi Jaffe, abordando sua experiência como filha de sobrevivente. $\mathrm{O}$ terceiro, mais curto, preenche as sete páginas finais e

\footnotetext{
${ }^{7} \mathrm{Um}$ dos aspectos marcantes de Maus é a incorporação vanguardista - em contraste com o formato habitual dos quadrinhos - de fotos, mapas, plantas e outros gêneros discursivos que acentuam o hibridismo da obra.
} 
é escrito por Leda Cartum, filha de Noemi, fornecendo o seu ponto de vista sobre o drama que ressoa na terceira geração da família. Se, por um lado, as ideias que Noemi Jaffe desenvolve e os eventos que rememora parecem eclodir diretamente do impacto gerado pela leitura do diário da mãe, numa relação paratextual, como defendido em estudo de Amanda Parisote (2016), por outro, o diário da mãe, com sua linguagem simples e despretensiosa, parece funcionar como um longo preâmbulo necessário para a emergência do ensaio vigoroso da filha. Como resultado, temos uma contiguidade e uma tensão entre as três partes do livro, como se elas compusessem um fragmentário quadro familiar que congrega uma identificação entre essas três gerações de mulheres, mas, ao mesmo tempo, ressalta três individualidades, três domínios discursivos e três modos, mais ou menos contraditórios, de pensar e sentir a catástrofe.

O diário da mãe foi depositado no Museu do Holocausto, em Jerusalém, e ao longo do livro não surgem dúvidas quanto à fidelidade estrita ao texto original. No entanto, a decisão de publicálo e a interpretação de sua singela escrita pertencem ao domínio da filha. É uma escolha ética importante o fato de, na organização interna do livro, o diário de Lili Jaffe ser apresentado em primeiro plano, do mesmo modo que é indiscutível sua relevância como documento testemunhal autônomo. Mas, na construção da unidade fragmentária do livro, o texto de Noemi Jaffe dilata e reconstrói vários sentidos do diário, apresentando fatos futuros ou omissões da mãe, de tal forma que a presença do diário no livro pode ser pensada não como um "anexo" ou o mote de uma longa glosa, mas, sim, como uma citação - ainda que abarque o texto integral - que energiza e penetra os outros dois textos.

A parte a que daremos mais relevo na análise é a escrita por Noemi Jaffe, composta por 36 pequenos capítulos intitulados com uma única palavra, geralmente substantivos secos e diretos, como "Pedra", "Amor", "Memória"... lembrando verbetes de uma enciclopédia. A exceção fica com o último capítulo, no qual essa escolha minimalista é quebrada por um título que segue lógica oposta, marcada pelo tamanho dilatado e a densidade poética: "O esquecimento é a única vingança e o único perdão". De um modo geral, predomina no texto uma verve ensaística, mas que se combina reiteradamente com passagens narrativas, incursões líricas, fluxo de 
consciência, roteiro teatral, emulação de documentos burocráticos e uma miríade de outras estratégias textuais. Há quatro eixos principais que se alternam nos capítulos: a interpretação do diário da mãe, a apresentação de seu drama como filha de sobrevivente, a história da família após o fim da guerra, com a reconstrução da vida no Brasil, e o relato das impressões causadas por uma viagem que as três mulheres do livro fizeram ao memorial de Auschwitz, no inverno de 2009. Unindo estes planos, temos os questionamentos sobre os limites da memória, sua relação com o esquecimento, as tensões entre lembrança e imaginação, além de reflexões intelectuais sobre os limites do testemunho.

Os capítulos de Noemi Jaffe iniciam-se, quase sempre, com observações sobre os temas aos quais dedica sua atenção: "Parece que a necessidade de comer, para quem passa fome, é mais forte do que a própria necessidade de viver" (Jaffe, 2012, p. 107). Fica a impressão de que haverá um desenvolvimento da tese apresentada, em moldes característicos do discurso acadêmico. O fascínio com a etimologia das palavras é uma tônica recorrente e ajuda a ressaltar a postura especulativa, o afã de entendimento que alimenta as buscas filosóficas da autora. Na mesma seara, podemos situar as referências eruditas que surgem abundantemente no texto, em especial por meio da retomada literal de escritores ligados à "literatura de testemunho", como Paul Celan, Elie Wiesel, Ruth Kluger, David Grossman e Primo Levi. Mesmo evitando os cacoetes da citação acadêmica, tais referências aproximam sua reflexão do gênero ensaístico, incorporando ao texto a atuação da filha como professora universitária.

No entanto, a tese apresentada no início de cada capítulo é rapidamente contraposta a outras linhas de pensamento, sofrendo uma fratura interna. Surge daí um tumulto de dúvidas, expressadas por perguntas retóricas que atravessam sua tentativa de compreensão, estabelecendo limites muito rígidos para o entendimento pleno dos dilemas enfrentados pela ação reflexiva. As conclusões que Noemi Jaffe nos apresenta - e são várias e intrigantes - estão marcadas por uma desconfiança fundante, inescapável, advindas de um terreno sabidamente hostil. São, enfim, conclusões que se sabem provisórias e desconfiadas de si mesmas: "O certo é que não é uma coisa nem outra" (Jaffe, 2012, p. 203), diz a filha, após 
longo colóquio sobre suas razões de escrever. Essa necessidade ininterrupta de compreender o horror, ao mesmo tempo em que se reconhece a irrepresentabilidade do vivido, é, como sabemos, um traço marcante nos testemunhos canônicos. Porém, na perspectiva dos filhos, o impasse parece, em alguns momentos, poder ser superado pela distância crítica do evento. Mas essa distância que promete entendimento cobra uma contraparte dolorosa, ligada tanto à culpa de não se ter passado pela dor dos pais como ao reconhecimento de que há algo ambíguo e cruel em tentar explicar o absurdo de uma dor que não se vivenciou de fato no próprio corpo.

\section{Entre ratos e ratoeiras}

Com Maus, Art Spiegelman inova ao trazer a representação da Shoah para as histórias em quadrinhos, uma linguagem que até então parecia imprópria ao tratamento exigido por esse tipo de temalimite. Os riscos da empreitada estariam ligados, sobretudo, às armadilhas por trás da encenação do horror pela indústria cultural, gerando uma estetização melodramática da catástrofe e sua consequente dissolução em um mercado cultural afoito para torna-la digerível e rentável (Adorno, 1998; Gagnebin, 2014). Ora, sendo as histórias em quadrinhos um dos veículos mais associados à comunicação de massas, os riscos de banalização da experiência e de deglutição pop do horror resulta, sem dúvida, numa escolha arriscada, que justificava desconfianças. Contudo, após a sua longa jornada de publicação, o livro recebeu uma acolhida bastante auspiciosa tanto do ponto de vista crítico como comercial (sendo o impacto desse êxito brilhantemente incorporado, como impasse ético, na segunda parte da obra).

A suspeita de que a linguagem performática dos quadrinhos não permitiria o tratamento cuidadoso que a matéria retratada demandaria foi, em grande medida, afastada por conta do rigor e da forma nada indulgente que Spiegelman adotou para falar de sua relação com o pai. Maus se converteu rapidamente num marco das narrativas gráficas, levando os quadrinhos a um público até então refratário ao caráter pueril e inconsequente associado ao gênero, contribuindo para sua legitimação enquanto objeto artístico. Ao mesmo tempo, indicou um amplo 
horizonte para o gênero, estimulando novos artistas a experimentarem formalmente e tematicamente em suas obras. Tudo isso enquanto revigorava a discussão sobre o testemunho, tornando-se uma obra incontornável dentro das discussões literárias e filosóficas sobre a representação da Shoah.

O enredo do livro é bem mais fácil de explicar que o da obra de Noemi Jaffe. Encontramos Artie - a encenação autobiográfica do autor - recolhendo depoimentos de seu pai, Vladek Spiegelman, sobre sua vida durante a guerra. Vladek, um judeu polonês, foi perseguido pelos nazistas, tornou-se prisioneiro de guerra e posteriormente foi enviado juntamente com Anja, sua esposa e mãe de Artie, para o campo de Auschwitz. Desde o início da narrativa, sabemos que as experiências lembradas pelo sobrevivente e transmitidas ao filho seriam material para um livro de quadrinhos, sendo a narrativa, portanto, uma representação metalinguística do processo de construção da obra. Num dos planos, temos o testemunho do pai, voltado para a recuperação do passado, no qual são rememorados acontecimentos da guerra. No outro, enfrentamos o presente, que ressalta, além do processo de construção do livro, as hesitações, dúvidas e impasses do autor ao lidar com o relato paterno.

Articulando esses dois níveis, temos a relação conflituosa entre Vladek e Artie, marcada por desencontros, diferenças geracionais e de visão de mundo, além de conflitos edipianos ligados, sobretudo, ao ressentimento do filho por conta do suicídio de sua mãe, ocorrido anos após sua libertação de Auschwitz. Em síntese, estamos diante da busca do filho por sua identidade, que só pode ser devidamente afirmada através do enfrentamento do drama familiar. Coexistem, em franco embate, o compromisso ético de preservar e transmitir, no plano coletivo, a história do pai, e o enfrentamento individual, via simbolização, dos traumas herdados pelo impacto da guerra, seja nos desencontros gerados pela postura mesquinha de Vladek em relação a vários aspectos da vida - com ênfase constante em seus preconceitos e teimosia -, seja no vazio traumático causado pelo suicídio da mãe. Desse modo, podemos resumir a apresentação da obra retomando as palavras de Larissa Silva Nascimento, segundo a qual:

Maus é um quadrinho autobiográfico, [...] Art expressa sua conturbada vivência ao lado de seu pai e o sofrimento causado pelo trauma de seus pais, que, de certa forma, 
também é seu. O livro é ainda biográfico por apresentar a perseguição que Vladek sofreu desde o início da guerra e que culminou no seu confinamento em Auschwitz. Art Spiegelman retrata a luta que seu pai travou contra a morte, a sua persistente vontade de viver (Nascimento, 2012, p. 28).

\section{O porta-voz: ladrão e protetor das memórias}

São muitas as semelhanças entre as duas obras. Em ambas vemos os filhos buscando nas histórias dolorosas dos pais a preservação da memória familiar e pistas para o autoconhecimento e o enfrentamento de traumas pessoais. Tanto Vladek Spiegelman quanto Lili Jaffe acabam reconstruindo suas vidas em outros espaços, tentando, talvez, fugir das ruínas de seus países natais, ele nos Estados Unidos e ela no Brasil. Os filhos nascem já nesse novo espaço, inseridos numa outra língua e cultura, sendo frutos desse lugar escolhido para o recomeço. O papel da língua, aliás, é fundamental nas obras. Vladek, primeiramente, teve no domínio do inglês uma arma de sobrevivência nos campos, visto que durante algum tempo obteve vantagens ensinando o idioma a um kapo. Apesar disso, sua fala é recriada no livro com ênfase no acento estrangeirado e duro de seu inglês, indicando sua não integração plena a esse lugar de recomeço. Em $O$ que os cegos estão sonhando?, o português peculiar de Lili também é assunto de discussão da filha e dessa reflexão sai a frase que dá título ao livro, retirada de uma pergunta linguisticamente acidentada, altamente reveladora da relação da mãe com o português e, por extensão, com o país que escolhe para viver após o fim da guerra.

Filho e filha assumem a obsessão de saber sobre o passado e quebrar o muro de silêncio montado pelos pais. Ambos estão em crise, sua identidade está cindida - como transparece quando relatam o contato prolongado que tiveram com seus respectivos terapeutas. Há, desse modo, um cruzamento constante entre o testemunho direto dos pais e o testemunho oblíquo, intelectualizado e cheio de nuances estéticas e considerações psicanalíticas e filosóficas, dos filhos. Assim:

O jovem sobrevivente quer esquecer, precisa esquecer, mas suas ações e sensações estão entrelaçadas e perpetuamente ligadas à 
Shoah. A segunda geração, que remonta e constrói suas memórias da infância, juventude e de toda uma vida recebe, de alguma forma essa culpa, essa dor, essa post-memory, e busca entendimento, conhecimento, explicação (Fux, 2013a, p. 51).

Em Maus o encadeamento entre o depoimento do pai e a história que nos é apresentada pelo filho ocorre num mesmo eixo estrutural. Descobrimos pouco a pouco os episódios que marcaram a experiência de sobrevivente de Vladek, que são coletadas pelo filho num processo que se assemelha aos métodos de registro da história oral. A narrativa do pai é intercalada por longas cenas de autoquestionamento do filho ou de interação com o pai e outros personagens, como sua namorada, Françoise, ou seu terapeuta, Pavel. Já no livro de Jaffe, o diário da mãe é apresentado como texto de abertura, portanto sem a alternância entre os dois testemunhos. Em tese, adentraremos nas indagações do texto já conhecendo os eventos centrais vividos pela mãe. Posteriormente, longas passagens do diário serão retomadas, inclusive por meio de citações literais, mas o encadeamento entre os testemunhos segue uma lógica que destaca a autonomia (relativa, como veremos) entre eles.

As relações entre realidade e ficção pululam nas duas obras, prologando, e em certa medida ampliando, algumas aporias típicas da produção testemunhal. Tratam-se de obras marcadas pelo compromisso com a veracidade dos acontecimentos narrados, pois o pacto autobiográfico é assumido tanto no plano da autoria como no dos narradores. Em breve comentário sobre Maus, Márcio Seligmann-Silva chama atenção para uma carta enviada por Art Spiegelman à redação do The New York Times Books Review, na qual reclama da classificação de seu livro entre as obras de "ficção". De acordo com o crítico, "Spiegelman aceita o teor 'literário' de sua obra, mas, como ele escreve com toda razão, isso não implica em afirmar o teor 'fictício' da mesma" (Seligmann-Silva, 2013, p. 381).

Tal compromisso com o "real" não implica o abandono de estratégias narrativas consagradas pelas artes plásticas e o gênero dramático (sobretudo em Maus) e pela poesia lírica e o ensaísmo (sobretudo em $O$ que os cegos estão sonhando?). O embate crucial se dá entre a responsabilidade ética diante da matéria abordada e das pessoas envolvidas e a necessidade de expressão esteticamente adequada, para além do registro documental frio e estéril. Os 
limites, negociações e tensões entre estes dois polos se manifestam de diferentes maneiras, mas parecem apontar para dificuldades comuns, típicas do testemunho oblíquo. Filho e filha manifestam uma preocupação genuína em não deformarem, exageraram ou ornamentarem a narrativa de seus progenitores. Entretanto, observamos que tais depoimentos são incorporados aos livros com pudor e um agudo reconhecimento da impossibilidade de retomada direta desses testemunhos.

Em Maus, Artie se preocupa, a certa altura, com o fato de o pai estar sendo representado como a caricatura do judeu avarento. Justifica-se, em seguida, afirmando que só deseja "fazer um retrato fiel dele" (Spiegelman, 2016, p. 134). Nesse caso, reconhece que a fidelidade estrita traz o inconveniente de reforçar um estereótipo, impactando tanto a dimensão ética do livro como incorporando um clichê artisticamente condenável. Por outro lado, atenuar, ignorar ou mascarar a mesquinhez do pai resultaria numa deformação igualmente problemática da realidade que se deseja registrar. Ser fiel ao relato do pai é, portanto, uma tarefa reconhecidamente difícil e delicada. Não é uma decisão estática, mas uma negociação interna constante.

No livro de Jaffe também são apontados o machismo da mãe, seus hábitos austeros que incomodavam as filhas e geravam atritos no seio familiar, escapando de qualquer idealização ou heroicização da sobrevivente. Mas o embate geracional, nessa obra, é equilibrado por uma cumplicidade entre as três mulheres do livro, pelo reconhecimento de certas qualidades herdadas e de uma identificação que ultrapassa os atritos. De certo modo, o implacável embate edipiano que acompanhamos em Maus é compensado no livro de Jaffe pela cumplicidade feminina e o amor filial que dispensa a compreensão absoluta. Sinal disso é que as referências ao pai em $O$ que os cegos estão sonhando? são circunstanciais, quase irrelevantes, enquanto em Maus a mãe é, de fato, uma ausênciapresente: seus diários são a grande esperança de Artie de alcançar uma visão mais acessível e humana do passado, sem a inflexibilidade das lembranças do pai. Ter acesso a esses textos seria sua fonte verdadeira de redenção, incapaz de ser alcançada por meio do relato paterno. Contudo, a busca pelos diários da mãe não será bem-sucedida, pois foram queimados por Vladek num momento de extremo desespero após a morte da esposa. Anja, a 
mãe, torna-se o que Levi chamou de "testemunha integral", e tanto o testemunho de Vladek (cujos momentos mais comovidos são os que falam sobre a esposa) quanto o de Artie buscam registrar a sua delicadeza, destroçada pelo peso do trauma.

É importante observar que em Maus os dois testemunhos se retroalimentam. Como esperado, o conteúdo da narrativa do pai impacta a busca pessoal engendrada pelo filho; mas, por outro lado, o relato paterno é igualmente impactado pela interlocução constante de Artie, que mais do que registrar mecanicamente a história, interage com Vladek, sendo também um editor de seu testemunho. Afinal, como autor do livro que lemos, é o filho quem seleciona as passagens que comporão a obra. Nesse processo, é certo que a unidade narrativa demanda ajustes na construção textual e, não nos esqueçamos, na representação visual do universo narrado. O filho faz constantes pedidos de esclarecimento, solicita detalhes de certas passagens, censura as constantes digressões do pai e pede para que ele narre a história numa ordem cronológica ou que explore mais situações particulares, para que deixe a história "mais real e humana" - algo que o pai nega de imediato: "posso contar outras histórias, mas coisas particulares eu não quero que você mencione" (Spiegelman, 2014, p. 25), pedido que o filho responde com uma promessa que, ao fim, não será cumprida.

Em $O$ que os cegos estão sonhando? esta mediação entre os testemunhos tenderia a ser menos imbrincada, já que se trata da reprodução literal e integral do diário da mãe. Em parte isso é verdade, e é esse o caminho que Amanda Parisote (2016, p. 31) utiliza, em artigo já citado, para defender que "é somente a partir dele [diário de Lili] que os textos de Noemi Jaffe e Leda Cartum ganham lugar", resultando no protagonismo e autonomia do diário em relação aos outros textos que compõem o livro. Mas vejamos alguns pontos que abalam a autonomia total entre os testemunhos que compõe o livro. Em primeiro lugar, a adoção, por parte da mãe, do gênero diário já estabelece um problema interessante. Obviamente era impossível manter esse tipo de registro dentro dos campos de concentração, por uma questão material elementar - de acesso aos instrumentos necessários para a escrita - e pelo esgotamento físico e psicológico a que eram submetidos os prisioneiros. Sendo o diário uma construção discursiva de caráter íntimo e que busca reconstituir na linguagem situações vividas ao longo 
de um período recente, um diário escrito a posteriori, depois do fim da guerra, revela, desde o início, o teor instável e híbrido do texto da mãe.

Ademais, quando perguntada pela filha sobre a razão de ter escrito o texto, a mãe responde: "para mostrar para você" (Jaffe, 2012, p. 207). Na dedicatória do diário, as filhas voltam a aparecer como destinatárias, como se fossem interlocutoras futuras daquelas palavras. Novamente, $\mathrm{o}$ modo como a mãe rompe as convenções em torno do gênero diário (texto íntimo, secreto, com observações, em geral, sobre o que foi vivido no próprio dia correspondente às anotações) atesta um enfoque muito peculiar para o seu testemunho e, quem sabe, semelhante aos textos de Anja, aos quais não temos acesso em Maus. Se não bastasse isso, a filha assume a condição de editora e revisora da tradução do diário. Fala bastante da "dificuldade muito grande de traduzir em forma apropriada os tempos verbais" (Jaffe, 2012, p. 191) utilizados pela mãe. $\mathrm{Na}$ apresentação do livro, deixa entrever suas escolhas em relação ao modo mais adequado de apresentar o diário: "Decidi manter aspectos particulares da escrita de minha mãe no diário, para preservar a espontaneidade e a intensidade com que ele foi escrito" (Jaffe, 2012, p. 7). Ou seja, além de intérprete, narradora e personagem de sua história, Jaffe acumula o papel de ser editora e supervisora da tradução do diário, reforçando o movimento de conjugação dos testemunhos da mãe e da neta ao eixo central criado pela filha.

Quero com isso dizer que a incorporação das narrativas dos pais nesses livros concebidos pelos filhos exige uma mediação autoral que desafia constantemente o compromisso com os fatos narrados tal como foram enunciados pelas testemunhas primárias. O processo é semelhante ao tratamento dado à identidade dos filhos. No capítulo "Terceira pessoa", Noemi Jaffe discorre sobre a opção de se referir a si mesma sempre na terceira pessoa do singular, convertendo-se numa personagem sem nome, mencionada apenas pela sua condição: "filha". Segundo ela, "a filha não quer explicar, não sabe muito bem. Não se sente bem contando essa história-não-história em primeira pessoa" (Jaffe, 2012, p. 188). Após enumerar algumas vantagens eventuais dessa escolha, decorrentes da constatação de que "o eu é uma armadilha" (p. 189), a autora conclui sua reflexão subvertendo a ideia defendida no início do capítulo. Afirma que seria corajoso adotar de uma vez por todas a primeira pessoa do singular: "tirar dele [relato] toda a carga estilística que a terceira 
pessoa empresta a ele e adotar a voz mais genuína de um relato" (p. 189). Nota-se, nesse movimento de afirmação, negação e síntese imperfeita de ideias, tão recorrente ao longo do livro, uma justificativa que é ao mesmo estética (formal) e psicológica. A escolha voluntária de um ponto de vista indireto tem como contraparte o reconhecimento de uma identidade fraturada que só pode se afirmar escondendo-se (descobrindo-se) nas tramas do relato da mãe, pois "A filha tem medo de dizer eu. É sua maneira de dizê-lo" (p. 189).

Penso que a antropomorfização adotada em Maus aponta para um problema semelhante na construção da identidade. Como se sabe, ao longo do livro, os judeus são representados como ratos, os alemães como gatos, os poloneses como porcos, os norte-americanos como cães, e assim por diante. Longe de configurar uma alegoria simples, como poderíamos acreditar à primeira vista, essa escolha é cercada de rasuras, que vão desde a referência irônica a Mickey Mouse - quando o pai se entusiasma diante da hipótese de os quadrinhos do filho alcançarem o sucesso e a rentabilidade da estrela de Walt Disney -; passam pela citação da história "Prisioneiro do planeta inferno", onde estão as únicas imagens com fisionomias "realistas" do livro, e que se opõem, pela virulência e desconforto que gera no pai, ao trabalho sóbrio que Spiegelman procura imprimir na obra; e chegam, enfim, às passagens em que Artie utiliza uma máscara de rato, como se sua identidade judaica fosse na verdade um disfarce estratégico ou um transe criativo, revelando uma reação ao mesmo tempo inescapável e artificial com o judaísmo. $\mathrm{O}$ personagem mascarado aparece exatamente nos momentos em que está incomodado com a celebridade alcançada com a publicação do primeiro volume da história e se prolonga na sessão de terapia com Pavel, quando o enfrentamento da sua própria identidade é focalizado.

Fabiano Andrade Curi nos lembra que "quem já teve contato com outros trabalhos do autor sabe que ele é capaz de elaborar ilustrações muito mais complexas do que as que estão em Maus" (Curi, 2009, p. 144). "Ilustrações mais complexas" se referem aqui à quantidade de detalhes na construção visual das personagens. A falta desses detalhes não significa superficialidade ou pobreza dos desenhos, ao contrário, a simplicidade das imagens é aqui decisiva para a força do conjunto. As imagens dos ratos são praticamente idênticas entre si: o que difere o pai do filho são basicamente os objetos que os acompanham - óculos, 
roupas e inclinação do corpo. A representação das personagens por meio de animais dispensa o autor de fazer uma representação realista de si mesmo, o que pode ser pensado como necessidade de deslocamento da identidade em crise. Vale lembrar que o livro incorpora fotografias do pai e de seu irmão Richieu, morto durante a guerra, como a nos lembrar que "aquela história aconteceu e que os ratos são uma representação, mas não uma ficção" (Curi, 2009, p. 144), porém não exibe nenhum retrato de Artie, desviando-se - assim como Noemi Jaffe - da focalização direta da imagem autoral: este eu biográfico que, não obstante, é paradoxalmente a tônica dos dois livros.

Marcada pelo trauma, a autorrepresentação dos filhos só pode se manifestar, nesses casos, por meio de estratégias formais que expandem e complexificam o teor autobiográfico das obras. Há um conflito que perpassa o estatuto desses testemunhos oblíquos: o sentimento de culpa, de incompreensão e impotência diante do sofrimento dos pais. Noemi Jaffe afirma sem margem para rodeios: "Ser filho de sobrevivente contém, em algum lugar remoto e inóspito da memória, a tentação de ter estado no lugar do sobrevivente [...] deixa nos filhos uma pequena culpa, uma pequena falta" (Jaffe, 2012 p. 115). Em Maus, num diálogo entre Artie e Françoise, o filho diz: "Sei que é maluquice, mas até que eu gostaria de ter estado em Auschwitz com meus pais para poder saber mesmo tudo o que sofreram!... Acho que é algum tipo de culpa por não ter passado pelo que eles passaram no campo de concentração" (Spiegelman, 2016, p. 176).

Não me parece desprovido de sentido o fato de Jaffe falar em estar "no lugar" dos pais e Spiegelman optar pela construção "estar com os pais", mas essa seria uma discussão que ultrapassaria os limites deste artigo. Destaco, porém, a semelhança entre essas duas comovidas, e ao mesmo tempo envergonhadas, confissões. O trauma dos campos parece querer pulsar em cada acontecimento de suas vidas, gerando uma sensação de desamparo diante de uma situação não vivida diretamente, e cuja possibilidade de ser traduzida em palavras desafia os limites da representação. Mesmo as situações mais triviais, os embates corriqueiros em qualquer família, as angústias que basta estar vivo para vivê-las, tudo ganha um contorno sombrio por conta da memória da guerra pairando no convívio afetivo dos sobreviventes. É como se a herança da Shoah impedisse os filhos de viverem os desencontros fortuitos do cotidiano, pois cada ato dos pais parece 
revelar um modo de estar no mundo marcado até o âmago pela experiência devastadora dos campos de extermínio e, por isso, incorporando novos sentidos, novas exigências interpretativas, até mesmo nas mais banais situações, como o modo de comer, a valorização do trabalho, a frieza para lidar com a dor, a austeridade de Lili, a sovinice de Vladek.

Em uma de suas constantes tentativas de interpretação do comportamento da mãe após a guerra, a filha se pergunta se é justo relacionar todas as suas características - sua indiferença diante de acidentes domésticos, sua robustez moral, sua obstinada crença de que "tudo se resolve", sua fúria diante do desperdício, enfim, as muitas facetas de sua personalidade - ao impacto direto do trauma. E responde em seguida que sim, que o efeito de uma experiência extrema como a dos Lagers ressignifica todas as atitudes da mãe e, por extensão, da família. É certo que, para a mãe, pouco importa destrinchar essa permanência, ao contrário, "o esquecimento é o eixo constitutivo de sua personalidade" (Jaffe, 2012, p. 125), mas para os herdeiros, sondar as frestas dessas memórias, decifrar o silêncio que elas revelam, é a única maneira de encontrar um lugar na família, um lugar no mundo e um lugar no presente. Retomando o artigo de Jacques Fux (2013a, p. 49), vemos que "Além da falta de entendimento, tanto em relação ao Acontecimento em si, também falta a eles [filhos] o conhecimento das limitações dos próprios pais. Noemi Jaffe relata, em vários momentos de seu testemunho, esse sofrimento dilacerante". Assim sendo, os dois livros são enfrentamentos de histórias ao mesmo tempo conhecidas e irreconhecíveis: conhecidas porque habitam desde o nascimento o imaginário dos filhos, mas irreconhecíveis porque só podem se tornar realmente significativas quando apropriadas simbolicamente por essa nova geração, alimentada pela imaginação e por fantasmas de um passado não vivido.

Reconstruir essa história é uma lâmina afiada e ambígua. A materialidade corrosiva do trauma dos pais ameaça desfalecer nas alegorias ensaiadas pela ânsia de compreensão dos filhos. Em Maus temos a alegoria dos ratos, comentada anteriormente. Em O que os cegos estão sonhando? é retomada em mais de um momento a alegoria da pedra: a pedra que os alemães obrigaram a mãe a carregar como punição a um desvio que ela assumiu a pedido de suas primas. A filha vê na imagem estática desse castigo uma imagem-síntese da catástrofe: 
a dor física e psicológica da humilhação de segurar por horas uma pedra pesada sobre a cabeça, por conta de uma falta que não cometeu. Mas a encenação "dramática" que a alegoria suscita incomoda a filha, sobretudo porque a lembrança que a mãe tem do episódio é penosamente literal, áspera, irredutível. Nesse jogo arriscado, o "fatopedra" triunfa (precisa triunfar) sobre a "pedra símbolo", pois a dor da mãe foi, sem dúvida, real, extrema, mas a dor da filha dói como trauma e dói ainda mais por se julgar caprichosa. Afinal, a resignação dos pais em seguir a vida e esquecer a catástrofe incomoda aos filhos, que a sofreram indiretamente e por isso precisam representá-la, ainda que essa retomada só possa surgir entrecortada pela representação estética. Portanto, a cena da catástrofe é reconstruída numa cadeia significativa que não é a dos pais, mas a de um passado herdado-imaginado que ameaça constantemente deformar o testemunho "real", diluindo-o no testemunho oblíquo.

Nesse ponto, podemos concluir que o testemunho oblíquo apresenta uma dimensão envergonhada e culposa, pois reconhece que se processa como desvio do testemunho "real" e enfrenta a culpa de refundá-lo numa outra linguagem. Artie afirma: "Só estou pensando no meu livro... É pretensioso da minha parte. Quer dizer, não consigo nem entender minha relação com meu pai... Como vou entender Auschwitz... ou o Holocausto?" (Spiegelman, 2014, p. 174). Jaffe compartilha o mesmo desconforto: "Qual será a reação da mãe", pergunta-se, "quando ela vir que este livro é um apanhado de retalhos, de divagações, de memórias soltas, de tentativas rasgadas de interpretação misturadas a lembranças coladas?" (Jaffe, 2012, p. 208).

Como forma de incorporar nas obras esse desajuste constitutivo, ambos desenvolvem uma contínua reflexão metalinguística. Em Spiegelman, a passagem na qual o autor incorpora o sucesso alcançado pelo primeiro volume do livro é bastante representativa da consciência que tem em relação ao sentido ambíguo de seu êxito. O procedimento lembra bastante a estratégia consagrada por Miguel de Cervantes no segundo volume de Don Quijote de la Mancha, na qual a recepção parcial da obra é ironicamente incorporada como parte do enredo. Num dos quadros visualmente mais impactantes de Maus, temos o escritor de cabeça baixa diante de sua prancheta, com sua aparência humana encoberta pela máscara de rato, cercado de cadáveres e moscas. Bem ao fundo, por detrás do vidro da janela, 
uma construção que lembra as torres de vigília de Auschwitz. No monólogo do personagem surgem informações sobre o sucesso de crítica e venda da primeira parte do livro, além de referências aos inúmeros convites financeiramente atraentes para adaptar a obra para o cinema e a tevê. Todos os elementos, visuais e textuais, convergem para a expressão da culpa que assola o filho, agora não mais apenas pela dor herdada como também pelo embaraço decorrente da visibilidade pública obtida por meio da encenação da catástrofe íntima que esfacelou a sua família.

Em $O$ que os cegos estão sonhando? a dúvida sobre o sentido de escrever sobre a tragédia familiar é encarada especialmente nos capítulos intitulados "Porta-voz" e "História". Neste, a autora antecipando-se à recepção do livro - menciona o júri de um concurso literário que, avaliando uma obra que abordava o nazismo, sentencia que "tudo já foi escrito sobre o assunto", que esse tema "já deu o que tinha dar, já cansou" e que toda menção artística a ele seria "uma oportunidade de exploração de um sofrimento que nunca acaba de se oferecer" (Jaffe, 2012, p. 184). Por mais que a afirmação do júri possa soar insensível ou drástica demais, ela é enfrentada pela autora como um incômodo justificável. Ela chega a reconhecer que a Shoah talvez tenha mesmo se esgotado enquanto fonte de aprendizado histórico ou social, mas, por outro lado, ressalta que a experiência individual que o horror dos campos gravou na vida de milhares de sobreviventes ainda exige uma tarefa ética de escuta e preservação que durará para muito além da existência dessas pessoas.

A função do texto seria, então, redimensionada para o caráter subjetivo da criação de uma memória conjunta. Desviando-se da função socialmente edificante, voltada para a luta por justiça histórica, que o testemunho canônico toma como imperativo, a autora apresenta uma das definições mais pungentes de sua obra: "O livro é só uma tentativa de uma filha conhecer melhor uma mãe" (Jaffe, 2012, p. 185). O termo "só" não significa que este objetivo seja fácil de se alcançar, ao contrário, em vários momentos se mostra cercado de lacunas e segredos intransponíveis, mas aponta para uma modéstia estratégica, que transfere a atenção da face enigmática da catástrofe para os sedimentos traumáticos que ela deixa na memória dos sobreviventes e de seu círculo afetivo mais próximo. 
O compromisso é composto tanto por um desígnio dos filhos quanto por uma delegação dos pais. Aqui indico, já à guisa de conclusão, um dos aspectos mais intrigantes no testemunho fornecido pelos pais: sua total falta de eloquência ou triunfalismo. Vladek parece narrar, antes de qualquer outra coisa, porque é uma das poucas maneiras de estar junto com Artie sem que as diferenças entre eles tornem o contato insuportável. Se a convivência entre os dois é truncada, permeada pela casmurrice do pai e a impaciência do filho, nos momentos em que grava sua história, as armas de ambos se abaixam e há um contato afetivo, ainda que tênue, entre os dois. A narrativa restabelece, por breves momentos, a cumplicidade entre eles. Fora isso, o pai narra com simplicidade e fluência quase documental; em raros momentos, a descrição de uma passagem terrível, como a morte do filho Richieu ou do sogro, embarga-lhe a voz. Em geral, as dificuldades de verbalização de suas memórias de guerra não ficam evidentes, pois, como ele mesmo afirma, já conhece muito bem sua história, como se coubesse aos outros, e não a ele, comoverem-se com ela.

Algo semelhante vale para o diário de Lili. Na ótica da filha, o diário ficou sendo a caixa preta de sua experiência nos campos, já que a mãe se esforçou em esquecer os eventos ali relatados. Coube ao diário ser o elo possível entre o passado da mãe e o presente da filha. A consumação desse elo precário, mas necessário e tenazmente bordado em insights críticos e poéticos, está condensada na figura do "porta-voz". O porta-voz seria aquele que guarda a voz: num gesto franco, espontâneo, confessional, ficcional, intelectual, doloroso e impetuoso, "ouve a voz que outra pessoa não emitiu" (Jaffe, 2012, p. 163). Se, por um lado, o porta-voz é um ladrão, pois, sempre segundo a autora, rouba a voz de outrem, que fica mudo, ele, por sua vez, rouba algo que o dono da voz deseja - precisa - que seja roubado e transmitido. Mesmo guiado pela responsabilidade de ser fiel à voz que lhe foi delegada, o porta-voz só pode dizer aquilo que o dono não saberia dizer, inventando uma nova linguagem, sempre além e aquém da narrativa alheia a que deve lealdade.

O testemunho primordial dos sobreviventes é conjugado, assim, numa outra forma, ecoando os sentidos do trauma, pois somente dos estilhaços daquele discurso é possível brotar o testemunho do outro: o testemunho oblíquo que amplifica o murmúrio onde apenas o silêncio do esquecimento prometia algum conforto. 


\section{Referências}

ADORNO, Theodor (1998). Crítica cultural e sociedade. In: ADORNO, Theodor. Prismas. Tradução A. Wernet e Jorge Almeida. São Paulo: Ática.

AGAMBEN, Giorgio (2014). O que resta de Auschwitz. Tradução de Selvino J. Assmann. São Paulo: Boitempo.

BERGER, Alan; BERGER, Naomi (Org.) (2001). Second generation voices: reflections by children of holocaust survivors perpetrators. New York: Syracuse University Press.

CURI, Fabiano Andrade (2009). Maus, de Art Spiegelman: uma outra história da Shoah. Síntesis, Campinas, v. 14, p. 140-158.

FUX, Jacques (2013a). Até quando os cegos continuarão sonhando? Revista de Letras, Fortaleza, v. 2, n. 32, p. 47-52, ago./dez.

FUX, Jacques (2013b). W ou o testemunho da infância. Letras de Hoje, Porto Alegre, v. 48, p. 459-466.

GAGNEBIN, Jeanne Marie (2014). Lembrar escrever esquecer. São Paulo: Editora 34.

HIRSCH, Marianne (2008). The generation of postmemory. Poetics Today, Durham, v. 29, n. 1, p. 103-128.

JAFFE, Noemi (2012). O que os cegos estão sonhando? - Com diário de Lili Jaffe (1944-1945) e texto final de Leda Cartum. São Paulo: Editora 34.

LEVI, Primo (1990). Os afogados e os sobreviventes. Tradução de Luiz Sérgio Henriques. Rio de Janeiro: Paz e Terra.

MARCO, Valéria de (2004). A literatura de testemunho e a violência de estado. Revista Lua Nova, n. 62, p. 45-68.

NASCIMENTO, Larissa Silva (2012). Para além das cercas de arame farpado: o Holocausto em Maus, de Art Spiegelman, e em Os emigrantes, de W. G. Sebald. Dissertação (Mestrado em Literatura e Práticas Sociais) - Universidade de Brasília, Brasília.

PARISOTE, Amanda Dal'Zotto (2016). Entre autoras, diários e memórias: a linguagem da barbárie em $O$ que os cegos estão sonhando? Revista do Instituto Cultural Judaico Marc Chagall, São Paulo, v. 8, n. 1, jan./jun.

SELIGMANN-SILVA, Márcio (Org.) (2013). História, memória, literatura: o testemunho na Era das Catástrofes. São Paulo: Editora da Unicamp. 
SPIEGELMAN, Art (2016). Maus. Tradução de Antonio de Macedo Soares. São Paulo: Cia. Das Letras.

WIESEL, Elie (1987). Holocausto: canto de uma geração perdida. Tradução de Roberto Raposo. São Paulo: Documentário.

Recebido em 15 de agosto de 2017.

Aprovado em 26 de maio de 2018.

\section{resumo/abstract/resumen}

\section{O testemunho oblíquo em $O$ que os cegos estão sonhando?, de Noemi Jaffe, e Maus, de Art Spiegelman}

Marcelo Ferraz de Paula

Este artigo desenvolve uma análise comparativa das obras $O$ que os cegos estão sonhando?, de Noemi Jaffe, e Maus, de Art Spiegelman. O exame crítico empreendido visa colocar em discussão algumas semelhanças no processo de construção da autoria nestes dois livros - particularmente no que se refere à autorrepresentação do drama dos filhos de sobreviventes dos campos de concentração nazistas - e no modo como estes relatos de segunda geração assumem a forma de um testemunho oblíquo, ao mesmo tempo prolongamento de e ruptura com os testemunhos dos pais-sobreviventes. Recorre-se, entre outras referências, às ideias de Márcio Seligmann-Silva (2013) e Giorgio Agamben (2014) a respeito da produção testemunhal e às discussões de Jeanne Marie Gagnebin (2014) sobre memória e esquecimento após Auschwitz.

Palavras-chave: Art Spiegelman, Noemi Jaffe, testemunho, memória.

\section{The oblique witness in $O$ que os cegos estão sonhando?, by Noemi Jaffe, and Maus, by Art Spiegelman}

Marcelo Ferraz de Paula

This article develops a comparative analysis of the works, O que os cegos estão sonhando?, by Noemi Jaffe, and Maus, by Art Spiegelman. The critical examination discusses some similarities in the process of how authorship is constructed in these two books. Particularly, the essay discusses the selfrepresentation of the children of Nazi concentration camps survivors, and the manner in which second generation narratives take the form of an oblique 
witness, which constitute, at the same time prolongation and rupture with the testimonies of surviving parents.

Keywords: Art Spiegelman, Noemi Jaffe, testimony, memory.

\section{El testimonio oblicuo en $O$ que os cegos estão sonhando?, de Noemi Jaffe, y Maus, de Art Spiegelman}

Marcelo Ferraz de Paula

Este artículo hace un análisis comparativo de las obras $O$ que os cegos estão sonhando?, de Noemí Jaffe, y Maus, de Art Spiegelman. El examen crítico emprendido pretende poner en discusión algunas similitudes en el proceso de construcción de autoría en estos dos libros, particularmente en lo que se refiere a la auto representación del drama de los hijos de sobrevivientes de los campos de concentración nazis, y al modo como estos relatos de segunda generación asumen la forma de un testimonio oblicuo, al mismo tiempo prolongación y ruptura con los testimonios de los padres-sobrevivientes.

Palabras clave: Art Spiegelman, Noemi Jaffe, testimonio, memoria. 